\title{
Passion to Profession: A review of Passion fruit Processing
}

\author{
Srishti Biswas', Ritesh Mishra², Ankur Singh Bist ${ }^{3}$ \\ School of Agricultural Sciences \& Engineering, IFTM University, Moradabad, 244102, Uttar \\ Pradesh, India \\ Signy Advanced Technologies, INDIA \\ e-mail:srishtibiswas12@gmail.com ${ }^{1}$, mishra.ritesh9@gmail.com ${ }^{2}$, ankur1990bist@gmail.com $^{3}$
}

Biswas, S., Mishra, R., \& Bist, A. S. (2021). Passion to Profession: A review of Passion fruit Processing. Aptisi Transactions on Technopreneurship (ATT), 3(1), 48-56.

DOI: https://doi.org/10.34306/att.v3i1.143

\begin{abstract}
Passion fruit (Passiflora edulis) is a nutritious tropical fruit that belongs to the family Passifloraceae. The purple passion fruit is local from southern Brazil through Paraguay to northern Argentina. For a long time, India has appreciated a moderate collection of purple passion fruit in the Nilgiris in the south and various parts of north India. The Passion fruit has a good amount of antioxidants, flavonoids, anti-inflammatory, anti-bacterial, anti-fungal, and antiaging properties. This fruit has huge economic importance as all the parts of this fruit (seed, peel, flower, pulp) are rich in medicinal and therapeutic properties. The fruit is a fantastic wellspring of dietary fiber, nutrients, Vitamin C, and Vitamin A. Being a decent laxative, it likewise secures the colon mucosa by diminishing openness time to harmful substances in the colon and clearing off the malignant growth causing poisonous substances from the colon. Passion fruit has several medical advantages and hence requires diverse processing and preservation methods. Here we are going to review a portion of these methods.
\end{abstract}

Keywords: Passion fruit, Anti-bacterial, anti-fungal, anti-ageing and preservation.

\section{Introduction}

The passion fruit (Passiflora edulis) familyPassifloraceae, is a native of Brazil. In India it is discovered to be filling wild in many parts of Western Ghats such as Nilgiris, Wynad, Kodaikanal, Shevroys, Coorg and Malabar as well as Himachal Pradesh and North Eastern States like Manipur, Nagaland and Mizoram. Passion fruit is commercially cultivated in the North Eastern States of Manipur, Mizoram and Nagaland. It is also cultivated in some parts of Nilgiris an Shevroys. It is a perennial woody fruit vine belongs to family Passifloraceae, native to tropical America (Brazil) [1], bears hermaphrodite, solitary flowers located in the leaf axils. The fruit is round or ovoid and has an intense, smooth, waxy dull purple or yellow tinted skin with weak, fine white spots. Inside, the fruit is pretty much loaded up with a sweet-smelling mass of twofold walled, membranous sacs containing orange shading thick squeeze and upwards of 250 little, hard, dim earthy colored to dark pitted seeds. It can grow rapidly under great conditions - up to six meters in one year. The evergreen leaves of the vine provide a shelter for the fragrant exotic looking white and purple flowers that appear on the new growth. A ripe fruit is reviving, sensitive flavor with satisfying smell and high nutritive worth. In India, passion fruit can successfully be grown well up to $2000 \mathrm{~m}$ altitude with an annual rainfall of 1000 to $2500 \mathrm{~mm}$. Fruits are widely acknowledged as important component of a healthy diet and adequate consumption could help to reduce a wide range of diseases [2]. The fruit is valued for its pronounced flavor and aroma which helps not only in producing a high quality squash but also in flavoring several other products. This nutritious fruit crop highly appreciated for fresh consumption and industrial purposes because of its excellent flavor and nutrition which is used for juice, jelly and ice cream products [3].Fruits have been a part of the human diet over the years. They contain high quantity of water, carbohydrate, sugars, vitamins, minerals and organic compounds which are required 
by the body to function well [4].To enhance the flavor of the final produce, passion fruit juice is often mixed with juices of pineapple, mango, ginger etc. The juice is extensively used in confectionery and preparation of cakes, pies and ice cream. It is a rich source of Vitamin A and contains fair amounts of Sodium, Magnesium, Sulphur and Chlorides. Commercial Processing of yellow passion fruit yields $36 \%$ juice, $51 \%$ rinds and $11 \%$ seeds [5].

\section{Types}

Out of 600 known species of Passiflora, in the familyPassifloraceae, only one P. edulis, sims, has been utilized for the edible purpose in India. Passiflora edulis exits in two distinct types known as Passiflora edulis sims the purple passion fruit and Passiflora edulis flavicarpa, the yellow passion fruit. The purple passion fruit is originally native of Tropical America, whereas yellow passion fruit is being considered as a mutation of the purple variety or as a natural hybrid between purple and another related species of passion fruit [6]. Passiflora quadrangular is L., the giant granadilla, is also cultivated to a limited extent for local consumption. It grows best in a hot, moist climate and produces a round or oblong, pale yellow to yellowish-green fruit when ripe, which may reach up to 8 inches in size. Passiflora foetida L., a wild species, bears very small fruits and has unique characters of being highly precocious and very short fruit maturity period [7]. Purple and yellow are commonly cultivated in northeast region of India, while Knavery (hybrid between purple and yellow) is common in south India [8].Two types of Passiflora edulis Sims (Passifloraceae) are grown commercially, the purple form (P.edulis Sims) and a yellow form (P. edulis var. flavicarpa DeGeneres) [9]. In Brazil, Passiflora alata is the official Passiflora species in the Brazilian Pharmacopoeia and P. edulis is the species most employed as a flavoring and as a juice in the food industries.

This tropical fruit is actually considered a type of berry, according to botanists. It is the fruit of the Passiflora vine, a type of passion flower. It has a tough outer rind and juicy, seedfilled center. Despite its small size, it's a rich source of antioxidants and contains a range of vitamins and plant compounds that could benefit your health.

Passion fruit (Passiflora edulis Sims.) belongs to family Passifloraceae which includes 12 genera with more than 500 species. Genus Passiflora has about 400 species out of which few are economic importance. Within these species there are two district forms i.e., the standard purple (P. edulis) and the yellow (P. edulis f. flavicarpaDeg.). The chromosome number ranging from $2 n=18$ to $2 n=22$ [10]. Below here is mentioned 12 species of Genus Passiflora [11]:

i. Passiflora Alta Dryland: It is native of Peru and Brazil. It is a woody vine cultivated in Brazil for its fruits.

ii. Passiflora antiqueness Karst. (Syn. P. valxsemii (Len.) Traina\& Planch.):It is native of Colombia and known as banana passion fruit. This species is also a woody vine cultivated for its fruit.

iii. Passiflora cearensis Barb : It is native of Brazil and cultivated for its fruits.

iv. Passiflora edulis Sims. : It is real passion fruit which is native of South Brazil. This species is widely distributed throughout the tropics and subtropics. The fruits are especially used for juice preparation.

v. Passiflora foetida L . : It is woody species native of West Indies and South America. It is distributed to many tropical countries in Africa and Asia where it has naturalized. The fruits are hardly edible however, in Malaysia and East Africa it is used as cover crop.

vi. Passiflora LaurifoliaL. : It is native of thickets and forest fringes of West Indies and North-East South America. Cultivated for fruits and spread throughout the tropics (Parse glove, 1968).

vii. Passiflora ligularis Juss: It is native of Tropical America and commonly known as Sweet granadilla. Its sweet fruits are much used in mountainous region of Mexico and central America).

viii. Passiflora maliformis L.: A vine native to Tropical America and cultivated for fruits.

ix. Passiflora mallissima (H.B.K.) Bailey. It is native of Andes and commonly known as Banana Passion fruit. It is especially cultivated in Ecuador and Bolivia.

x. Passiflora psilatha(Sondrio) Kilip: It is native of Ecuador and known as Gullan. It is a vine grown for fruits. 
xi. Passiflora quadrangular is L. : It is commonly known as Giant granadilla and Barba dine and native of tropical South America. Widely distributed in tropics where it is grown for fruits.

xii. Passiflora tripartite (Juss) Poir: It is native of Ecuador and cultivated for fruits. It is commonly known as Tasco.

\section{Varieties}

Passion fruit has two distinct forms, the standard yellow (Passiflora edulis f. flaavicarpa Deg.) and the purple (Passiflora edulis f. edulis). The yellow are more acidic and less starchy while the purple are less acidic and more starchy. Both two form viz., purple passion fruit ( $P$. edulis) and yellow passion fruit (P. edulis var.flavicarpa) are of commercial importance. The hybrids of these two have also been developed for cultivation. The most popular passion fruit cultivated for their edible fruits have been discovered, which can vary in size and color. These most commonly available varieties are.

\subsection{Purple Passion Fruit}

Vines are productive at higher elevations. Fruits are $4-5 \mathrm{~cm}$ in diameter, deep purple when ripe each weighing 35-45 g. The juice content varies from 31-35 per cent. The variety is known for its quality in terms of flavor and nutrient content. Seeds are black in color. The variety is susceptible to leaf spot, collar rot, attack by trips and nematodes. The juice content of the fruit varies from $35-38 \%$ and has a better flavor and aroma as fresh, canned and frozen juice or pulp than the yellow one. The seeds are black in color. The commercial cultivars of the purple form are Ouropretano, Muico, Peroba, Pintado etc. in South America. In India, there is no standard cultivar. The local lines such as Ooty Purple, Coorg Purple Moodabidri Purple, Thrissur Purple, Cher punji Purple, Thalipramba Purple, Ambalavaval Purple etc. are cultivated by the growers [12].

\subsection{Giant Granadilla}

The hybrids of yellow and purple form have been developed for combining the desirable characteristics of both the forms of passion fruits. Several hybrid varieties have been developed in Brazil, Australia ,south Africa, etc. In India, a hybrid "Kaverii" of purple and yellow form was developed at Central horticultural Experimental Station, Chattily, Coorg, Karnataka. This variety is a high yielding hybrid developed from Central Horticultural Experiment Station, Chattily in 1986. This is a cross between purple and yellow varieties. The fruits are ovoid to round and purple dotted in color. The average fruit weight ranges between 90-100 g. Each plant bears 4060 fruits per annum. The average yield of a grown up orchard is around 60-70 tons per year. Its fruit yield is around 200 tons per ha over a three-year cropping period. Fruits contain 25-30 per cent juice, $11.5-12.0$ percent sugars and $3.0-3.5 \mathrm{mg}$ citric acid/100ml of Juice. This is tolerant to Alternaria leaf spot, Fusarium collar rot and nematodes. This variety is popular in Karnataka, Kerala, Tamilnadu and North Eastern States.

\section{Importance of Passion Fruit}

Passion fruit is a good source of nutrients, especially fiber, vitamin C and vitamin A. Raw passion fruit is $73 \%$ water, $22 \%$ carbohydrates, $2 \%$ protein and $0.7 \%$ fat (table) [13]. In a 100 gram amount, fresh passion fruit supplies 97 calories, and contains $36 \%$ of the Daily Value (DV) of vitamin C, $42 \%$ dietary fiber, B vitamins riboflavin (11\% DV) and niacin (10\% DV), $12 \%$ iron and $10 \%$ phosphorus (table) [14]. It's also rich in beneficial plant compounds, including carotenoids and polyphenols [15]. Passion fruit is a high acid food $(\mathrm{pH} \sim 3.2)$ due to the predominance of two acids, citric and malic acid. It is also rich in minerals like $\mathrm{K}, \mathrm{P}, \mathrm{Ca}, \mathrm{Fe}, \mathrm{Na}$, $\mathrm{Mg}, \mathrm{S}, \mathrm{Cl}$ and protein (Table 1) [16]. Passion fruit is also known as a nutritionally dense fruit, based on the level of nutrients present. The high amount of vitamin A, C and B2 in passion fruit is the primary driver of such nutritional scores. Nutritional composition of passion fruit per $100 \mathrm{~g}$ is enumerate in Table 1 [17]. The fruit has a high content in nutraceuticals, as phenolic acids, where anthocyanin's and flavonoids are the majoritarian compounds of this group; carotenoids and $\beta$-carotene appear to be the principal component, with consequently increased pro vitamin A activity. These nutraceutical compounds have biological activities in the health, protective effect against degenerative and chronic diseases and act as mutagenesis and carcinogenesis 
inhibitors. Also, these compounds have been associated with antiviral, anti-allergic, antiplatelet and anti-inflammatory activities [18] [19] [20] [21].

The presence of pythoconstituents like Alkaloids, phenols, glycosylic flavonoids and cyanogenic compounds make this fruit beneficial for the treatment and prevention of diseases such as anxiety, diabetic, cardiovascular diseases, sedative, convulsive, asthma, osteoarthritis and cancer. In several preclinical experiments, P. edulis extracts have exhibited potential effects for the treatment of inflammation, pain, and insomnia as well as for attention-deficit hyperactivity disorder, hypertension, and cancer. The juices extracted from pulps of P. edulis, P. maliformis and $\mathrm{P}$. quadrangular is possessed a rich source of fiber, protein and carbohydrate content. A cup of $247 \mathrm{~mL}$ Passiflora fruit juices provided $24 \%$ of $\mathrm{K}, 60-80 \% \mathrm{Mg},>80 \% \mathrm{P}$ and $90 \% \mathrm{Fe}$ of recommended dietary allowance of minerals [22]. Several mechanisms, including the inhibition of proinflammatory cytokines, enzyme (myeloperoxidase) and mediators (bradykinin, histamine, substance $\mathrm{P}$, nitric oxide) release and/or action, appear to account for $\mathrm{P}$. edulis actions. The leaves and stems of $P$. edulis have shown anti nociceptive, antitumor, antimicrobial, and antioxidant activities. This plant-based, traditional medicine system still acquires an important place in the health care system. The pulp of the fruit acts as a stimulant and tonic. Many practitioners actually use $\mathrm{P}$. edulis extracts alone or in combination with other herbal medicines to treat depression and insomnia in a wide range of patients [23] [24].

Table 1: Nutritional composition of passion fruit (Passiflora edulis) per 100g

Nutrients
Energy
Carbohydrate
Protein
Total Fat
Cholesterol
Dietary Fiber

\section{Vitamins}

Folates

Niacin

Pyridoxine

Riboflavin

Thiamin

Vitamin A

Vitamin C

Vitamin E

Vitamin $\mathrm{K}$

\section{Electrolytes}

Sodium

Potassium

\section{Minerals}

Calcium

Copper

Iron

Magnesium

Phosphorus

Selenium

Zinc

Nutrient value per $100 \mathrm{~g}$
$97 \mathrm{~K} \mathrm{Cal}$
$23.38 \mathrm{~g}$
$2.20 \mathrm{~g}$
$0.70 \mathrm{~g}$
$0 \mathrm{mg}$
$10.40 \mathrm{~g}$

Percentage of RDA

$5 \%$

$18 \%$

$4 \%$

$3 \%$

$0 \%$

$27 \%$

$14 \mu \mathrm{g}$

$1.500 \mathrm{mg}$

$0.100 \mathrm{mg}$

$0.130 \mathrm{mg}$

$0.00 \mathrm{mg}$

1274 IU

$30 \mathrm{mg}$

$0.02 \mu \mathrm{g}$

$0.7 \mathrm{mg}$

$3 \%$

$9 \%$

$8 \%$

$10 \%$

$0 \%$

$43 \%$

$50 \%$

$<1 \%$

$0.5 \%$

$0 \mathrm{mg}$

$348 \mathrm{mg}$

$0 \%$

$7 \%$

$12 \mathrm{mg}$

$1.2 \%$

$9.5 \%$

$20 \%$

$7 \%$

$10 \%$

$1 \%$

$1 \%$ 


$\begin{array}{ll}\text { Phyto-nutrients } & \\ \text { Carotene- } \beta & 743 \mu \mathrm{g} \\ \text { Crypto-xanthine- } \beta & 41 \mu \mathrm{g} \\ \text { Lycopene } & 0 \mu \mathrm{g}\end{array}$

Source: USDA National Nutrient data base. United States Department of Agriculture, Agricultural Research Service National Nutrient Database for Standard Reference Release 27 Software v.2.2.6 The National Agricultural Library [25].

Table 2: Physic-chemical composition of various species of passion fruits (\% per $100 \mathrm{~g} \mathrm{DW})$

\begin{tabular}{|c|c|c|c|c|c|c|}
\hline Species & $\begin{array}{l}\text { Moisture } \\
\text { content }\end{array}$ & Ash & $\begin{array}{l}\text { Crude } \\
\text { protein }\end{array}$ & $\begin{array}{l}{ }^{*} \text { Crude } \\
\text { fiber }\end{array}$ & $\begin{array}{l}\text { Crude } \\
\text { fat }\end{array}$ & $\begin{array}{l}\text { Carbohydrat } \\
\text { e }\end{array}$ \\
\hline $\begin{array}{l}\text { P.Edulis } \\
\text { (Purple) }\end{array}$ & $\begin{array}{l}85.45 \pm 0.5 \\
6\end{array}$ & $\begin{array}{l}1.18 \pm 0.11 a \\
b\end{array}$ & $\begin{array}{l}2.81 \pm 0.1 \\
9\end{array}$ & $\begin{array}{l}4.31 \pm 0.3 \\
1\end{array}$ & $\begin{array}{l}0.50 \pm 0.1 \\
4\end{array}$ & $6.95 \pm 0.73$ \\
\hline $\begin{array}{l}\text { P.Edulis } \\
\text { (Frederick) }\end{array}$ & $\begin{array}{l}84.37 \pm 0.6 \\
3\end{array}$ & $1.03 \pm 0.03$ & $\begin{array}{l}2.40 \pm 0.1 \\
1\end{array}$ & $\begin{array}{l}3.47 \pm 0.2 \\
6\end{array}$ & $\begin{array}{l}0.51 \pm 0.1 \\
0\end{array}$ & $7.44 \pm 0.69$ \\
\hline P. maliformis & $\begin{array}{l}85.44 \pm 0.3 \\
6\end{array}$ & $0.91 \pm 0.01$ & $\begin{array}{l}2.20 \pm 0.1 \\
4\end{array}$ & $\begin{array}{l}3.63 \pm 0.1 \\
8\end{array}$ & $\begin{array}{l}0.45 \pm 0.0 \\
2\end{array}$ & $7.17 \pm 0.64$ \\
\hline $\begin{array}{l}\text { P.quadrangul } \\
\text { a }\end{array}$ & $\begin{array}{l}86.16 \pm 0.4 \\
6\end{array}$ & $1.37 \pm 0.14$ & $\begin{array}{l}2.35 \pm 0.0 \\
9\end{array}$ & $\begin{array}{l}2.40 \pm 0.1 \\
1\end{array}$ & $\begin{array}{l}0.35 \pm 0.0 \\
1\end{array}$ & $6.57 \pm 0.29$ \\
\hline P. edulis & 84.70 & 1.00 & 2.80 & 3.30 & 0.50 & 7.39 \\
\hline $\begin{array}{l}\text { P.edulis } \\
\text { flavicarpa }\end{array}$ & 84.21 & 0.70 & 0.67 & 0.20 & 0.18 & 14.25 \\
\hline
\end{tabular}

SOURCE: Ramaiya, S.D., 2Bujang J.B., 3Zakaria, M.H. and 1 Saupi.N. 2019. Nutritional, mineral and organic acid composition of passion fruit (Passiflora species). Food Research 3 (3) : 231 - 240. ISSN: 2550-2166

\section{Post-Harvest Management of Passion Fruit}

Passion fruit has various little hard seeds which makes it troublesome as a table leafy foods its business significance exists in preparing, processing and value addition. There is an immense interest for blended fruit juices in Indian just as abroad business sectors, passion fruit juice or its mix with different fruits and vegetables have an extraordinary potential to drift in the market. The first harvesting is done after 1-2 years of planting and a healthy plant produces about 150-180 fruits per year. Passion fruit is manually picked by chopping or clipping the fruit from the vine. To help avoid water loss and fungal growth, a small piece of stem, around $4 \mathrm{~cm}$ (1.5 inches) in length, should be left attached to the fruit [26]. The storage of purple passion fruit at $10 \pm 2^{\circ} \mathrm{C}$ and $75 \% \mathrm{RH}$ is recommended for the three maturity stages tested because of the absence of chilling injury and better keeping quality during the shelf life period [27].

\subsection{Cleaning}

Depending upon the volume of fruit to be cleaned, the cycle should be possible manually or automatically. Automatic operations utilize overhead splash wash framework to clean to the fruit. To evade the spread of disease, the water utilized for washing should be consistently cleaned by keeping a $150 \mathrm{ppm}$ sodium hypochlorite concentration and a water $\mathrm{pH}$ of 6.5. Subsequent to washing, the fruit should be air dried prior to grading or sorting. 


\subsection{Grading/Sorting}

The Pre-sorting of fruit should be carried out in the field, and additional grading performed at the packing area to remove fruit that does not meet market requirements. The fundamental qualities utilized in grading passion fruit are size, skin color and uniformity, shape, firmness, and the amount of surface blemishes. Three different grades have been established by the National Bureau of Standards for domestic marketing of passion fruit (Grade 1, Grade 2, and Grade 3).

\section{Grade 1}

\section{Grade 2}

\section{Grade 3}

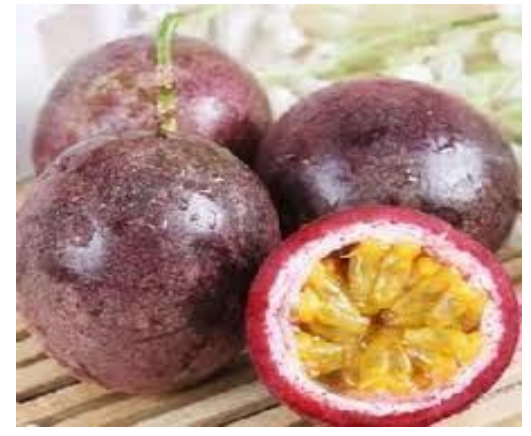

These passion fruits should be of acceptable quality, although $10 \%$ of the fruit in this grade may be soft or give indications of withering, and won't have a shiny appearance
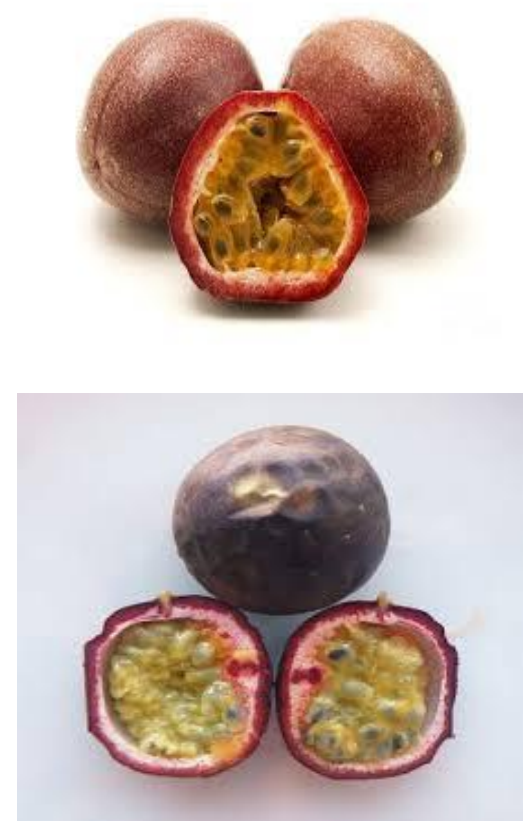

Passion fruit should be divided into 3 diverse size classifications from 4 to $9 \mathrm{~cm}$ in diameter and 4 to $12 \mathrm{~cm}$ long. The average diameter for fruit classified as small size is $5 \mathrm{~cm} \mathrm{(2}$ inch), for medium size is $6.5 \mathrm{~cm}$, and for large size fruit is $8 \mathrm{~cm}$.

External color tone is another significant quality characteristic utilized in sorting passion fruit. Prior to packing it is important to look for uniformly colored fruit in each container. The fruit should have a minimum of $75 \%$ of the surface area coloured to type (i.e. yellow or purple). Internal fruit quality should be checked on randomly selected fruit. Soluble solids content (SSC) of marketable fruit should range between $10 \%$ and $18 \%$ for yellow passion fruit and between $10 \%$ and $20 \%$ for purple passion fruit. Acidity of the pulp should range from $3 \%$ to $5 \%$. 


\subsection{Waxing}

Passion fruit may benefit from a postharvest wax application. Much of the fruit's natural wax is removed during washing, so it should be replaced. Waxing enhances the shine and external appearance of the fruit, reduces postharvest weight loss, minimizes shriveling, and extends market life. A carnauba-based wax is preferred for passion fruit. A liquid paraffin wax dip may also be used, but it is costlier and does not impart a shine on the fruit surface. After waxing, the fruit is packed for market.

\subsection{Packing}

A well-ventilated containers capable of being stacked without damaging the fruit is used for packing of passion fruit. Passion fruit are packed typically in large synthetic mesh sacks for export market and wooden containers or durable plastic crates are preferred for the domestic market. Ventilation holes are desired for horizontal air movement and efficient cooling. During shipment the carton should also have vents for vertical air flow.

\subsection{Processing of passion fruit}

The main objective of processing technique is to enhance the keeping quality of perishable fruit and minimize the qualitative and quantitative deterioration of the fruit and its products.

\subsection{Fruit pulps and juices}

Pulp or juice of passion fruit is extracted by straining the seed from the fruit content. With the help of additives, the juice can be stored from six months to more than year. During off seasons, the stored juice can be utilized for making different variants of beverages for consumption.

\subsection{Dehydrated products}

It is a less difficult technique for preparing and expansion of storage life by physical removal of water, by hot air drying, which is affordable on commercial scale. Here the fresh material is dried to residual moisture of about $5 \%$ and depending upon the required retention of pigmentation, flavor and taste, pre-treatment need to be ascribed. The dried material can be rehydrated using water. The storage life of dried material can be of a half year at room temperature. This process provides the scope for better storage and transportation due to reduction in bulk weight. Osmodehydrated and intermediate moisture products of $\sim 25 \%$ water content can be used for direct consumption without the need of re-hydration.

\subsection{Freezing of pulps}

In order to expect least or no changes in the stored fruit pulp, it is advisable to hold the fruit pulp prepared in a hygienic condition, in frozen condition at $-30^{\circ} \mathrm{C}$. The storage life would be minimum of six months. The frozen pulp after thawing can be reconstituted to obtain RTS drinks.

\subsection{Aseptic packaging}

Here the fruit pulp or juice is passed through computerized equipment with set temperature, duration and flow rate for processing and filling into sterile containers for storage and transport. The principle behind is high temperature short time (HTST).

\subsection{Micro-filtration}

After suitable dilution or the juice extracted is passed through ceramic membrane with micro pores. In fact, this technique can also serve to render stability to the product if operated under strictly sterile conditions. The greatest advantage of this process is a high degree of juice clarification and also prevention of discoloration over a course of storage life.

\subsection{Jam, jelly and marmalade}

Using pectin as a setting agent, fruit pulp can be converted to jam, whereas juice can be transformed into jelly under definite conditions of sugar and pectin concentrations. 
Marmalade represents a product like jelly including a bitter principle, usually as bits of citrus peel.

\subsection{Pickles}

Raw fruit can be converted into pickle after mixing in salt along with chili powder, followed by seasoning in hot oil of saturated fatty acids to overcome the rancidity during prolonged storage. To avoid the freight charges of wet pickle and convenience of handling, salting and dehydration into "instant pickles" can be packed along with chili, salt and spice powder. Upon reconstitution in water overnight the dry pickle can be converted into wet pickle.

\subsection{Bakery products}

Fruit pulp or its dehydrated product can be utilized for preparation of biscuits, cookies, fruit cake and muffins. After juice extraction, fruit pomace can be utilized in amalgamation with bakery flour to give bakery products better functionality due to balanced ratio of soluble/insoluble fiber, better hydration properties, and confer better sensory properties.

\section{Value Addition}

Value is added to the fruit by changing their form, color in order to increase the shelf life of perishable fruit. In the current scenario, there is an urgent need to increase the level of value addition and to improve the quality of value added fruit products for domestic and export market. Passion fruits are primarily used for food, in the form of value added products like juices, jams, jellies, ice creams and liquors. It is known for its sedative property, but its attractive aroma and flavor make the passion fruit an important product for the industry. The leaves and juice contain pass florin, a natural sedative, and tea prepared with leaves has a diuretic effect. It also shows purgative, sedative and anti-inflammatory properties. The seeds act as anthelminthic. It is popularly believed that the tea leaves, besides acting as a sedative, are also an effective antipyretic and help to treat skin inflammation, but these two uses are based on popular beliefs.

\section{Byproducts and Waste Management}

The processing of fruits leads to large amounts of by-products that may have functional properties. The waste resulting from passion fruit processing consists of more than $75 \%$ of the raw material. The rind constitutes $90 \%$ of the waste and is a source of pectin (20\% of the dry weight). Passion fruit seed oil is rich in linoleic acid (65\%). Nearly $40 \%$ of passion fruit production is directed to the juice industry. Large amounts of by-product (seeds and peels), that contains functional substances, are carried in passion fruit juice processing. The rind can be utilized for pectin production which is one of the major additive in confectionery industries whereas the seeds which represent about $6 \%$ to $12 \%$ of the total fruit weight can be utilized for oil extraction. The oil yield from the dry seeds of passion fruit reaches about $25 \%$. One hectare can produce approximately $480 \mathrm{~kg}$ of dry seed, which equals $96 \mathrm{~kg}$ of oil when using cold extraction.

\section{Conclusion}

Considering the above factors, it is possible to infer that the cultivation and processing of passion fruit is technically feasible and can be expanded in the region. The first and most important step to be taken is to raise public interest and provide widespread publicity by various channels, followed by the development of coordinated initiatives among all potential stakeholders, such as farmers and government agencies, research institutions and other agencies. Strategies such as proper post-harvest management, the development of proper storage facilities, the development of improved packaging for transportation, the improvement of transportation facilities, the establishment of new processing units, and the strengthening of existing processing units will undoubtedly increase passion fruit production in the region.

\section{References}

[1] R. J. Knight Jr and H. F. Winters, "Pollination and fruit set of yellow passionfruit in Southern Florida," 1962.

[2] C. Winston and L. Beck, "Phytochemicals: health protective effects," Can. J. Diet. Pract. 
Res., vol. 60, no. 2, p. 78, 1999.

[3] B. M. Santos, "Influencia de la fertilización nitrogenada en la interferencia de Digitaria sanguinalis sobre maracuyá," 2002.

[4] V. O. Onibon, F. O. Abulude, and L. O. Lawal, "Nutritional and anti-nutritional composition of some Nigerian fruits," J. Food Technol., vol. 5, no. 2, pp. 120-122, 2007.

[5] P. P. Joy, "Status and prospects of passion fruit cultivation in Kerala: Pineapple research station," India Kerala Agric. Univ., 2010.

[6] E. K. Akamine and G. Girolami, "Pollination and fruit set in the yellow passion fruit," 1959.

[7] J. Hatchinson, "The genera of the flowering plants:(Angiospermae) based principally on Genera plantarum of G. Benthum and JD Hooker, Vol II." Clarendon Press, Oxford, 1967.

[8] K. Kishore, K. A. Pathak, R. Shukla, and R. Bharali, "Studies on floral biology of passion fruit (Passiflora spp.)," Pakistan J. Bot., vol. 42, no. 1, pp. 21-29, 2010.

[9] K. C. Spencer and D. S. Seigler, "Cyanogenesis of Passiflora edulis," J. Agric. Food Chem., vol. 31, no. 4, pp. 794-796, 1983.

[10] P. C. Tripathi, "Passion fruit," Brillion Publishing New Delhi, 2018.

[11] A. C. Zeven and J. M. J. De Wet, Dictionary of cultivated plants and their regions of diversity: excluding most ornamentals, forest trees and lower plants. Pudoc, 1982.

[12] P. Zas and S. John, "Diabetes and medicinal benefits of Passiflora edulis.," World $\mathrm{J}$. Pharm. Res., vol. 5, no. 3, pp. 453-465, 2016.

[13] "Passion fruit nutrition facts and health benefits." [Online]. Available: Nutrition And You.com.

[14] USDA Nutrient, "Nutrition facts for Passion-fruit, (granadilla), purple, raw, 100 g." http://nutritiondata.self.com/facts/fruits-and-fruit-juices/1987/2 (accessed Apr. 02, 2013).

[15] S. T. Talcott, S. S. Percival, J. Pittet-Moore, and C. Celoria, "Phytochemical composition and antioxidant stability of fortified yellow passion fruit (Passiflora edulis)," J. Agric. Food Chem., vol. 51, no. 4, pp. 935-941, 2003.

[16] I. Noburu, A. Himki, A. Dithi, K. Kano, and M. Anggraeni, "Covid-19: Portrait of Preservation of the Batik Industry as a Regional Autonomy," Aptisi Trans. Technopreneursh., vol. 2, no. 2, pp. 143-152, 2020.

[17] Castañeda-Ovando A, Pacheco-Hernández ML, Páez-Hernández ME,Rodríguez JA, Galán-Vidal CA. Review: chemical studies of anthocyanins. Food Chem. 2009;113:859871. doi: 10.1016/j.foodchem.2008.09.001.

[18] A. Castaneda-Ovando, "de Lourdes., Páez-Hernández, Ma. Elena., Rodríguez, José A., Galán-Vidal, CA 2009. Chemical studies of anthocyanins: A review.” Elsevier Science BV.

[19] J. González-Gallego, M. V. García-Mediavilla, S. Sánchez-Campos, and M. J. Tuñón, "Anti-inflammatory and immunomodulatory properties of dietary flavonoids," Polyphenols Hum. Heal. Dis., pp. 435-452, 2014.

[20] C. A. Morais, V. V. de Rosso, D. Estadella, and L. P. Pisani, "Anthocyanins as inflammatory modulators and the role of the gut microbiota," J. Nutr. Biochem., vol. 33, pp. 1-7, 2016.

[21] B. Tanwar and R. Modgil, "Flavonoids: Dietary occurrence and health benefits," Spat. Dd, vol. 2, no. 1, pp. 59-68, 2012.

[22] S. D. Ramaiya, J. B. Bujang, M. H. Zakaria, and N. Saupi, "Nutritional, mineral and organic acid composition of passion fruit (Passiflora species)," Food Res., vol. 3, no. 3, pp. 231-240, 2019.

[23] L. A. Anderson, C. A. Newall, and J. D. Phillipson, Herbal Medicines: A guide for healthcare professionals. Pharmaceutical Press, 2002.

[24] Y. J. Zhou, F. Tan, and J. Deng, "Update review of Passiflora," Zhongguo Zhong yao za zhi= Zhongguo zhongyao zazhi= China J. Chinese Mater. medica, vol. 33, no. 15, pp. 1789-1793, 2008.

[25] U. Rahardja, A. S. Bist, M. Hardini, Q. Aini, and E. P. Harahap, "Authentication of Covid19 Patient Certification with Blockchain Protocol," Int. J. Adv. Sci Technol, vol. 29, no. 8s, pp. 4015-4024, 2020.

[26] K. Usha, M. Thakre, A. K. Goswami, and N. G. Deepak, "Fundamental of Fruit production," Div. Fruits Hortic. Technol. Indian Agric. Res. Institute, New Delhi, vol. 110, no. 012, pp. 1-245, 2015. 
[27] A. Sema and C. S. Maiti, "Status \& Prospects of Passion Fruit Industry in Northeast India," Cent. Inst. Hortic. Medziphema-797, vol. 106, 2006. 